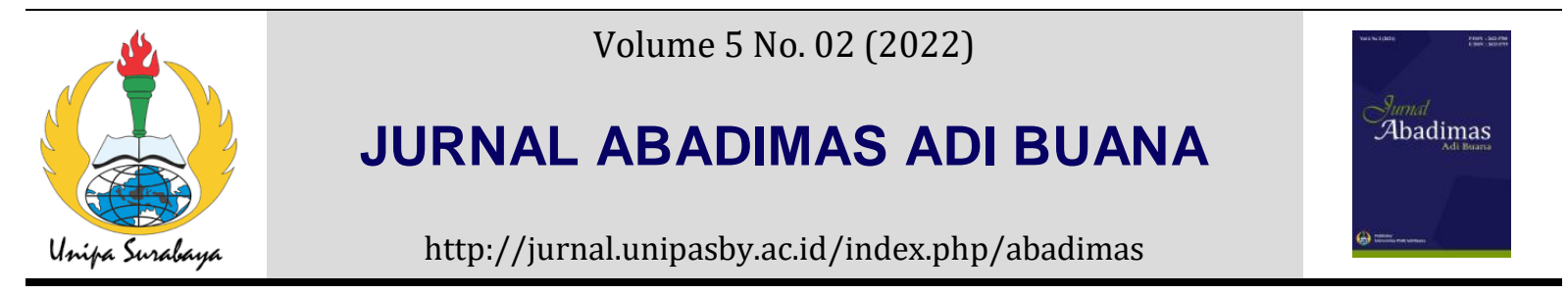

\title{
PELATIHAN BAHASA INGGRIS KEPARIWISATAAN BAGI PELAKU WISATA DI KAMPUNG HERITAGE KAYOETANGAN KOTA MALANG
}

\author{
Putu Dian Danayanti Degeng ${ }^{1 *}$,Irene Nany Kusumawardani ${ }^{1}$, Moh. Hasbullah Isnaini ${ }^{1}$, \\ Galuh Indah Asri ${ }^{1}$ \\ ${ }^{1}$ Pendidikan Bahasa Inggris, Fakultas Ilmu Budaya, Universitas Brawijaya, Malang, Indonesia
}

*Email: dian_degeng@ub.ac.id

\begin{abstract}
Informasi Artikel Abstrak
Kata kunci:

ETP, Bahasa Inggris untuk kuliner dan keramah-tamahan, kampung tematik.

Diterima: 13-07-2021

Disetujui: 05-01-2022

Dipubikasikan: 28-012022

Perkembangan pariwisata di Kampung Tematik Heritage Kayoetangan Kota Malang belum diimbangi oleh peningkatan kualitas sumber daya manusia yang berkecimpung di dalamnya. Meskipun kampung ini sering dikunjungi wisatawan asing, namun para pelaku wisata masih banyak yang belum menguasai Bahasa asing, khususnya Bahasa Inggris. Hal ini tentunya akan mempengaruhi kualitas layanan yang diberikan kepada wisatawan asing yang sebagian besar tidak menguasai Bahasa Indonesia. Solusi yang ditawarkan kepada mitra untuk mengatasi permasalahan tersebut adalah dengan mengadakan pelatihan Bahasa Inggris kepariwisataan (English for Tourism and Hospitality Purposes/ETP). Bahasa Inggris kepariwisataan yang diajarkan menyangkut kosakata untuk kuliner dan keramah-tamahan dikarenakan banyak pekerja wisata yang memiliki warung/toko namun terkendala bahasa sehingga tidak dapat mempromosikan usahanya dengan baik. Pelatihan ini diadakan pada bulan Agustus-September 2019 dan diikuti oleh 20 peserta. Selama $8 x$ pertemuan, peserta diajarkan berbagai kosakata dan cara penggunaannya dalam konteks nyata. Pelaksanaan pelatihan mampu menjadi solusi yang dihadapi mitra untuk meningkatkan kualitas layanan.
\end{abstract}

\section{Keywords :}

ETP, English for culinary and hospitality, thematic village

\section{Abstract}

The tourism development in Kampoeng Heritage Kayoetangan Malang is still not supported by the quality of the tourism doers. Although visited by foreigners, many tourism workers who also the front-liners are still not mastering the foreign language, especially English. This condition influenced the service quality. The best solution to this problem is by having English for Tourism and Hospitality workshop which assists them to provide better service. The theme for the workshop were English for Culinary and Hospitality since many tourism workers in this place own food stalls, yet they do not know how to speak English well to promote the products. This workshop was conducted in August-September 2019 and 20 people participated. The participants learnt the theory of Hospitality in 
English and practiced it within eight meetings. The result of this workshop can be a solution for Kampoeng Heritage Kayoetangan tourism doers to enhance their service quality.

\section{PENDAHULUAN}

Keterampilan untuk menguasai bahasa asing sangat dibutuhkan bagi mereka yang bekerja dalam sektor pariwisata dan keramah-tamahan (Mantra, 2020; Ya-Yu Cloudia, 2020). Semua aktifitas yang melibatkan penduduk lokal dan wisatawan pastinya membutuhkan komunikasi yang interaktif, terlebih mereka yang ingin secara profesional meningkatkan kualitas pelayanan jasa pariwisatanya (Bobanovic, 2011). Kualitas layanan merupakan salah satu komponen penting yang dapat mendukung pariwisata berkelanjutan (Prihandoko et al., 2019). Berkaitan dengan hal tersebut, bahasa Inggris sebagai sarana komunikasi, negosiasi dan transaksi yang dilakukan antara penyedia jasa dan turis sangat dibutuhkan untuk memberikan pelayanan yang lebih baik kepada wisatawan serta memberikan informasi secara tepat dalam sektor pariwisata (Prachanant, 2012). Untuk memenuhi kebutuhan ini, Bahasa Inggris kepariwisataan pada akhirnya muncul, dan secara khusus membahas mengenai aspekaspek bahasa Inggris yang dibutuhkan.

Bahasa Inggris kepariwisataan dan keramah-tamahan merupakan bagian dari English for Spesific Purposes (ESP) dan memegang peranan yang sangat penting dalam kualitas pelayanan dalam bidang pariwisata. Terlebih lagi ketika pariwisata tersebut mempunyai visi untuk go international, maka kebutuhan akan English for Tourism and Hospitality (ETP) tidak bisa dielakkan. Hsu (2011) menyatakan bahwa "ESP is considered as a main subject or topic that can promulgate competence into the hospitality and tourism preparation and training programs" (dikutip dalam Zahedpisheh, B Abu Bakar, \& Saffari, 2017). Dengan kata lain, ETP sebagai bagian dari ESP sangat dibutuhkan bagi mereka yang terjun dalam bidang pariwisata untuk memaksimalkan pelayanan atau keterampilan yang mereka kerjakan, sekaligus untuk meraih ruang lingkup pasar atau sasaran yang lebih luas (M Blue \& Harun, 2003).

Kampung Heritage Kayoetangan (KHK) merupakan salah satu kampung tematik yang ada di kota Malang. Kampung ini terdiri atas 4 RW, yakni RW I, RW II, RW IX, dan RW X (Wahyunik, n.d.) Daya tarik utama yang ditawarkan adalah wisata heritage karena kawasan ini termasuk permukiman kota tua Malang. Wisata heritage menawarkan pengalaman tempat, artefak dan aktivitas yang secara autentik menyajikan cerita masa lalu dan masa sekarang (Hargrove dalam Rasoolimanesh et al., 2021). Terdapat sekitar 30 rumah yang telah diresmikan sebagai rumah yang memiliki nilai sejarah dan terbuka untuk turis lokal dan mancanegara. Setelah diresmikan pada tahun 2018, berbagai upaya telah dilakukan Kelompok Sadar Wisata (Pokdarwis) KHK untuk mempromosikan potensi wisatanya. Potensi daerah yang luar biasa ternyata belum diimbangi oleh kesiapan pelaku wisata lokal untuk memberikan layanan, khususnya kepada tamu asing. Para pelaku wisata di KHK belum menguasai Bahasa asing, khususnya Bahasa Inggris. Keterampilan berbicara dalam bahasa Inggris 
perlu dikuasai oleh pelaku wisata (Firharmawan \& Andika, 2019). Penguasaan keterampilan ini tentu akan mempengaruhi kualitas layanan yang diberikan kepada tamu asing yang berkunjung.

Berdasarkan data yang didapatkan dari Dinas Kebudayaan dan Pariwisata Kota Malang, pelatihan bahasa Inggris pariwisata secara intensif belum pernah dilaksanakan di KHK. Hal ini disebabkan oleh belum tersedianya tenaga pengajar atau sukarelawan yang menginisiasi dan bersedia memberikan pelatihan bahasa Inggris kepada pelaku wisata di tempat tersebut. Oleh karena itu, tim dosen dan mahasiswa Pendidikan Bahasa Inggris, Jurusan Pendidikan Bahasa, Fakultas Ilmu Budaya, Universitas Brawijaya memandang perlu untuk mengadakan pelatihan Bahasa Inggris bagi pelaku wisata khususnya di KHK. Kegiatan ini bertujuan untuk memberikan pelatihan mengenai penggunaan bahasa Inggris khususnya kosakata dan istilah dalam English for Tourism and Hospitality Purposes (ETP) secara baik dan benar.

\section{METODE}

Metode pelatihan yang digunakan adalah metode pelatihan berdasarkan kebutuhan (Training Need Assessment) melalui pendekatan induktif. Metode ini dipilih berdasarkan kebutuhan dan karakteristik peserta. Berdasarkan permasalahan mitra terkait kesiapan memberikan layanan kepada tamu asing, maka pelatihan Bahasa Inggris Kepariwisataan ini difokuskan pada kosakata untuk kuliner dan keramah-tamahan. Kegiatan pelatihan Bahasa Inggris Kepariwisataan yang diperuntukkan bagi para pelaku wisata di KHK ini diadakan sebanyak delapan kali pertemuan (@ 2 jam) setiap hari Senin dan Sabtu. Pelatihan diadakan pada tanggal 19 Agustus - 14 September 2019. Pelatihan diadakan secara rutin di Balai RW KHK atau rumah warga serta diikuti oleh 20 peserta yang dipilih berdasarkan penunjukkan dari Pokdarwis. Peserta pelatihan terdiri atas pemilik warung/café, anggota Pokdarwis, ketua RT/RW. Untuk keperluan pelatihan, telah disusun modul English for Tourism in Kayutangan yang digunakan dalam setiap pertemuan.

\section{HASIL DAN PEMBAHASAN}

Kegiatan pelatihan dibuka oleh ketua tim pengabdian dan dihadiri oleh Ketua Pokdarwis dan peserta pelatihan. Acara pembukaan dilakukan pada tanggal 19 Agustus 2019. Setelah acara pembukaan, kegiatan dilanjutkan dengan pelatihan pertemuan pertama. 


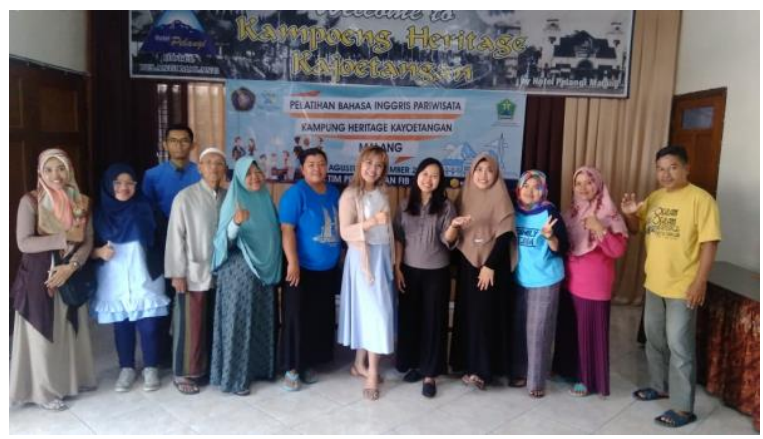

Gambar 1. Pembukaan pelatihan Bahasa Inggris

Sebelum mengikuti pelatihan yang diadakan oleh tim pengabdian, didapati bahwa kemampuan Bahasa Inggris para pekerja wisata di KHK pada umumnya masih lemah. Mereka bahkan tidak tahu bagaimana cara memperkenalkan diri dalam Bahasa Inggris. Oleh karena itu, pada pertemuan pertama peserta diajak untuk belajar memperkenalkan diri dengan mengacu pada Modul yang telah disusun. Pada pertemuan ini, tim pengabdian melakukan pembenahan kesalahan pelafalan beberapa kosakata yang sangat sering muncul dan digunakan dalam percakapan sehari-hari para pelaku wisata.

Pertemuan kedua diadakan pada tanggal 23 Agustus 2019. Pertemuan ini diawali dengan mengulang kembali beberapa poin penting mengenai cara memperkenalkan diri sekaligus meminta beberapa peserta pelatihan baru untuk mempraktikkannya.

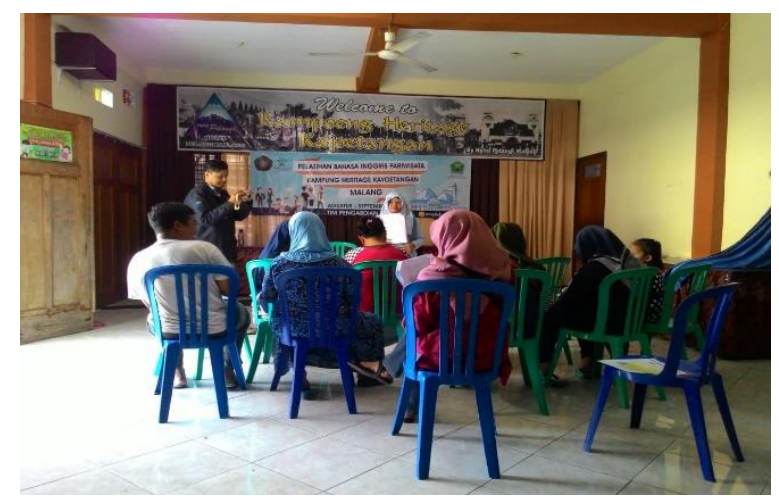

Gambar 2. Praktik perkenalan diri

Setelah itu, tim pengabdian bertanya perihal ketersediaan pembayaran tiket jika ingin memasuki KHK dan meminta perwakilan peserta untuk memberikan contoh bagaimana cara bertransaksi tiket. Tim pengabdian menemukan fakta bahwa tidak semua peserta pelatihan bahkan warga KHK menggunakan bahasa Inggris pada saat menerima pengunjung asing, dikarenakan turis asing yang berkunjung sudah membawa pemandu wisata sendiri, dan hal ini juga disebabkan minimnya SDM yang mampu berkomunikasi dengan bahasa Inggris. Akhirnya tim pengabdian pun berusaha menyadarkan peserta pentingnya untuk bisa dan terbiasa menggunakan bahasa Inggris sebagai pelaku wisata. Mereka pun mulai terbuka dan ingin berbagi pengalaman kesulitan-kesulitan 
pada saat melayani turis asing pada tim pengabdian. Pertemuan kali ini diisi dengan sesi saling berbagi pengalaman, poin-poin penting dalam melayani pembelian tiket, dan mempraktikkan beberapa contoh percakapan di modul yang sudah disiapkan.

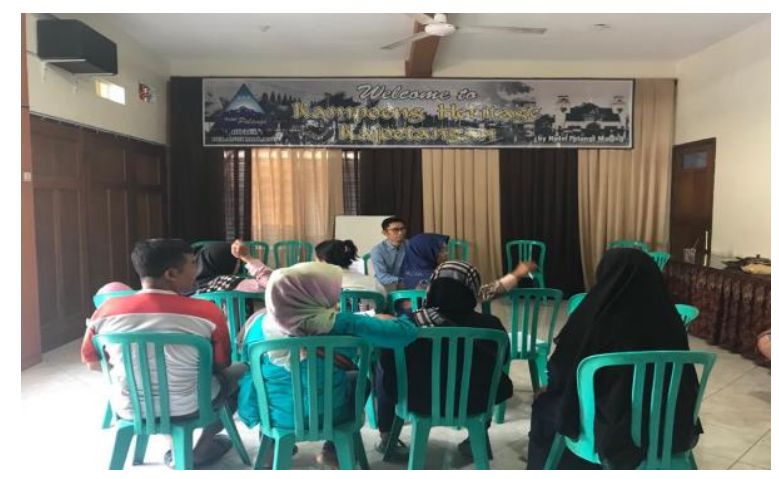

Gambar 3. Sesi berbagi pengalaman

Pertemun ketiga diadakan pada tanggal 26 Agustus 2019. Para peserta pelatihan mulai terbiasa dengan cara mengajar bahasa Inggris tim pengabdian yang mengedepankan fun and learning. Terlebih tim pengabdian memberikan kesempatan bagi perwakilan peserta untuk mempraktikkan materi how to be a tour guide dengan memberikan arahan jalan dan menggunakan kata depan dalam bahasa Inggris.

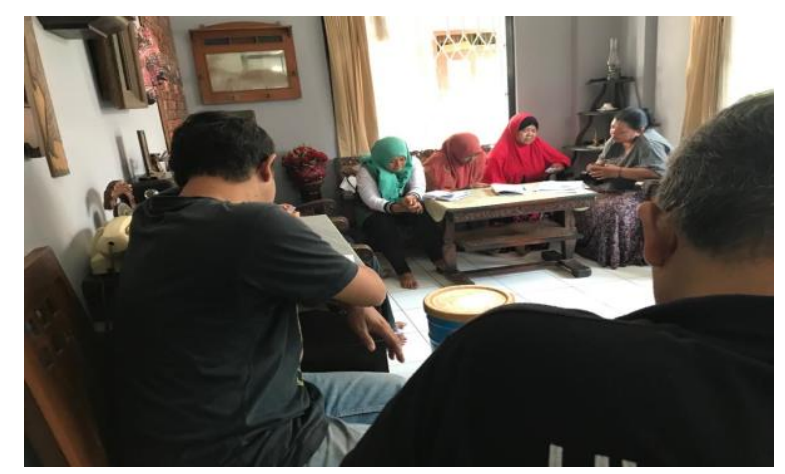

Gambar 4. Persiapan praktik "How to be a Tour Guide"

Pertemuan keempat diadakan pada tanggal 31 Agustus 2019. Peserta pelatihan belajar banyak kosa kata mengenai makanan dan minuman. Di pertemuan ini, peserta pelatihan lebih difokuskan pada pelatihan pelafalan kosakata dan percakapan mengenai how to serve guest dan presenting food. 


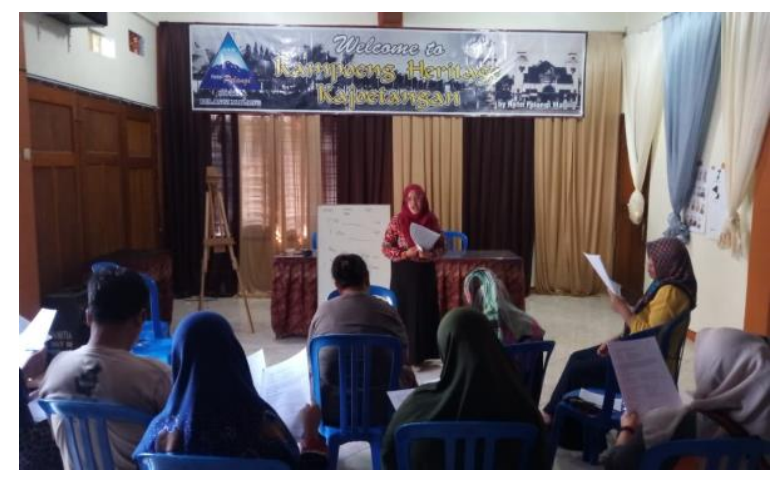

Gambar 5. Berlatih kosakata dan pelafalan

Pertemuan kelima yang diadakan pada tanggal 2 September 2019 ini berfokus pada melatih penggunaan angka, mata uang, dan waktu dalam bahasa Inggris. Pada saat belajar mengenai angka, mayoritas peserta pelatihan cukup lancar dalam pelafalan angka puluhan hingga ratusan. Sedangkan dalam pelaksanaan belajar tema mata uang, tim pengabdian membawakan contoh uang kertas ribuan hingga puluhan ribu dan juga uang logam.

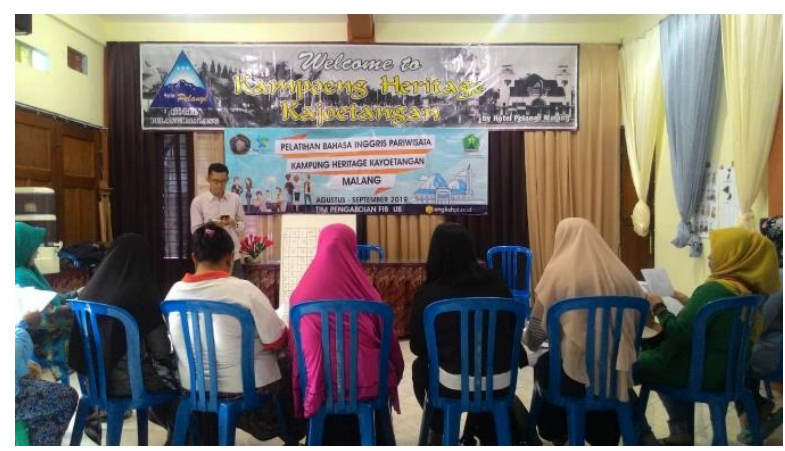

Gambar 6. Belajar mata uang

Peserta pelatihan, terlebih para Ibu terbilang sangat antusias dibandingkan para Bapak, karena mereka lebih sering bertransaksi. Satu persatu mereka menyebutkan nominal uang dalam bahasa Inggris. Sedangkan untuk mempelajari jam, tim pengabdian menghubungkannya dengan aktivitas keseharian para peserta, sehingga mereka lebih mudah menghafal dan mengaplikasikan ilmunya.

Pertemuan keenam diadakan pada tanggal 7 September 2019. Pertemuan ini merupakan momen di mana peserta pelatihan secara berpasangan dipersiapkan untuk turun ke jalan-jalan sekitar kampung untuk berlatih cara memberi arahan. Sesuai dengan yang telah dipelajari, para peserta mulai mempraktikkan untuk memberi arahan pada pasangannya. Ada beberapa pasangan yang lupa dengan alamat yang dituju, sehingga mereka harus benar-benar menyusuri jalan sembari menghafal jalan mana dan dibelokan keberepa mereka harus belok dan berhenti. Hal inilah yang menjadikan pertemuan ini menjadi lebih seru dan memberikan pengalaman nyata pada peserta.

Pertemuan ketujuh diadakan pada tanggal 9 September 2019. Pertemuan ini diisi dengan kegiatan praktik mendeskripsikan makanan dan minuman yang telah dibawa oleh masing-masing 
peserta pelatihan. Sebelumnya, tim pengabdian memberikan sedikit review mengenai bagaimana cara untuk mendeskripsikan makanan, bahan baku yang dipakai, dan rasa. Mulai dari rawon, pecel, cenil, hingga es campur sudah tersedia di meja untuk diperkenalkan. Masing-masing peserta pelatihan diminta berdiri di depan dan membawa makanan/minuman yang akan dideskripsikan. Mayoritas dari mereka sudah mampu mempresentasikannya dengan baik dan benar, meski ada beberapa pelafalan kosakata yang perlu diperbaiki. Namun ada juga peserta yang tampak malu-malu dan gugup saat presentasi sehingga memilih untuk memberikan sedikit deskripsi dan meminta peserta lain untuk memberikan contekan jawaban untuk tiap-tiap bahan yang tidak diketahui.

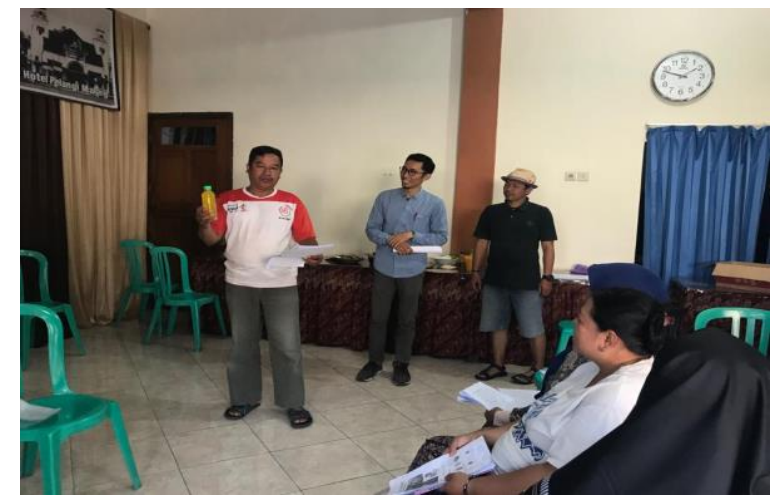

Gambar 7. Praktik mendeskripsikan makanan dan minuman

Pertemuan terakhir diadakan pada tanggal 14 September 2019. Pertemuan ini terbilang sangat mengesankan dan menarik bagi tim pengabdian dan peserta pelatihan. Di pertemuan ke 8 ini, dilakukan evaluasi sesuai dengan materi yang telah diajarkan selama 7 pertemuan. Evaluasi dilakukan dengan cara meminta peserta pelatihan untuk unjuk performa antara lain perkenalan diri, memberi arahan/petunjuk tempat dan mendeskripsikan makanan/jajanan kepada turis asing yang sedang berkunjung ke KHK.

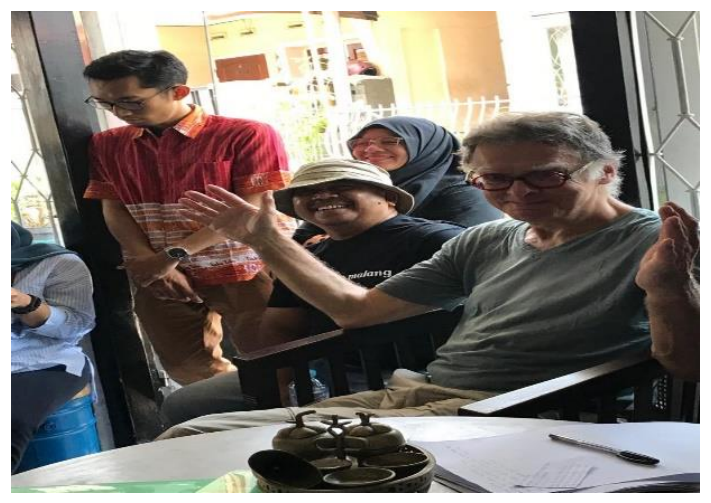

Gambar 8. Praktek berbicara dengan Turis Asing 


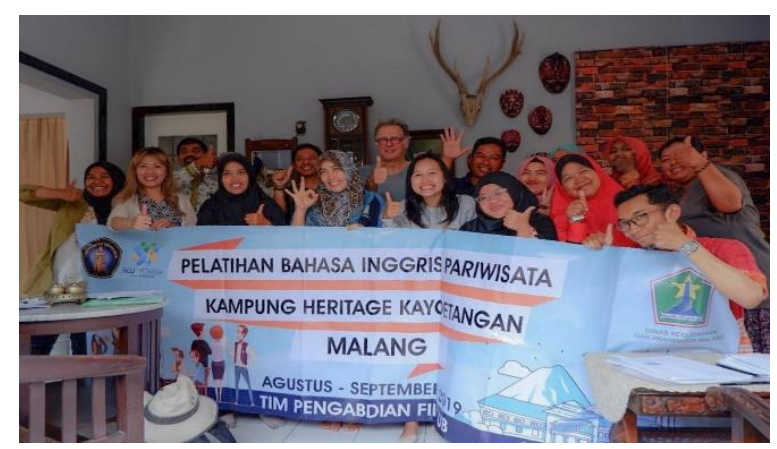

Gambar 9. Penutupan Pelatihan

\section{KESIMPULAN}

Pelatihan Bahasa Inggris memberikan banyak manfaat bagi para pelaku wisata di KHK, salah satunya adalah mengenai cara berkomunikasi dalam bahasa Inggris. Kegiatan ini dapat menjadi solusi untuk permasalahan yang dialami mitra. Hal ini ditunjukkan dengan meningkatnya kemampuan bahasa Inggris, khususnya untuk kebutuhan layanan mempromosikan kuliner lokal dan rumah bersejarah. Peserta pelatihan yang juga pelaku wisata di KHK merasa lebih percaya diri untuk berbicara dalam bahasa Inggris, dan hal ini terlihat dari antusiasme mereka ketika berkomunikasi dengan turis asing yang sedang berkunjung. Tantangan utama yang dihadapi tim pengabdian adalah seringnya pergantian peserta selama pelatihan yang disebabkan karena kesibukkan mereka. Saran untuk pelatihan selanjutnya adalah lebih memperhatikan waktu luang peserta untuk mendapatkan hasil pelatihan yang lebih maksimal.

\section{UCAPAN TERIMAKASIH}

Ucapan terima kasih disampaikan kepada Fakultas Ilmu Budaya Universitas Brawijaya yang telah mendukung pendanaan kegiatan ini. Tim pengabdian juga mengucapkan terima kasih kepada Dinas Kebudayaan dan Pariwisata kota Malang, Kelompok Sadar Wisata Kampung Tematik Heritage Kayoetangan, dan EnglishPlus.ID atas kerjasamanya sehingga kegiatan pelatihan ini dapat terlaksana dengan baik.

\section{DAFTAR PUSTAKA}

Bobanovic, K. (2011). The importance of English language skills in the tourism sector: A comparative study of students/employees perceptions in Croatia. Journal of Tourism, Culture. and Territorial Development, 2(4), 14. https://doi.org/10.6092/issn.2036-5195/2476

Firharmawan, H., \& Andika, A. (2019). Needs And Problems In English For Hospitality Industries: A Case Study Of The Hotel Employees At Meotel Hotel Kebumen. Journal of English Language Learning, 3(2), 61-67. 
M Blue, G., \& Harun, M. (2003). Hospitality language as professional skill. English for Specific Purposes, 22, 73-91. https://doi.org/10.1016/S0889-4906(01)00031-X

Mantra, I. B. N. (2020). English Language Urgency For Tourism And Hospitality Employees To Boost Global Economy. PalArch's Journal of Archaeology of Egypt, 17(7), 12.

Prachanant, N. (2012). Needs Analysis on English Language Use in Tourism Industry. Procedia Social and Behavioral Sciences, 66, 117-125. https://doi.org/10.1016/j.sbspro.2012.11.253

Prihandoko, L. A., Tembang, Y., Marpaung, D. N., \& Rahman, F. (2019). English language competence for tourism sector in supporting socio-economic development in Merauke: A Survey Study. IOP Conference Series: Earth and Environmental Science, 343, 012170. https://doi.org/10.1088/1755-1315/343/1/012170

Rasoolimanesh, S. M., Seyfi, S., Hall, C. M., \& Hatamifar, P. (2021). Understanding memorable tourism experiences and behavioural intentions of heritage tourists. Journal of Destination Marketing \& Management, 21, 100621. https://doi.org/10.1016/j.jdmm.2021.100621

Wahyunik, S. (n.d.). Menyusuri Kampung Heritage Kayutangan, Kota Malang, Wisatawan Bisa Nikmati Aneka Rumah Lawas. Surya Malang. Retrieved August 12, 2019, from https://suryamalang.tribunnews.com/2018/04/22/menyusuri-kampung-heritage-kayutangan-kotamalang-wisatawan-bisa-nikmati-aneka-rumah-lawas

Ya-Yu Cloudia, H. (2020). Communicative language teaching and English as a foreign language undergraduates' communicative competence in Tourism English. Journal of Hospitality, Leisure, $\begin{array}{lllll}\text { Sport } \& \text { Tourism } & \text { Education, 27(November } 2020),\end{array}$ https://doi.org/10.1016/j.jhlste.2020.100271

Zahedpisheh, N., B Abu Bakar, Z., \& Saffari, N. (2017). English for Tourism and Hospitality Purposes (ETP). English Language Teaching, 10(9), 86. https://doi.org/10.5539/elt.v10n9p86 